\title{
Parasitic infections in live freshwater tropical fishes imported to Korea
}

\author{
Jeong-Ho Kim*, Craig James Hayward, Seong-Joon Joh, Gang-Joon Heo \\ Laboratory of Aquatic Animal Diseases, College of Veterinary Medicine and Research Institute of Veterinary Medicine, \\ Chungbuk National University, Cheong-ju, 361-763, Korea
}

\begin{abstract}
We examined 15 species of ornamental tropical fishes originating from Southeast Asia to determine the cause of losses among 8 fish farms in Korea. A total of 351 individuals belonging to 5 different families (1 species of Characidae, 6 of Cichlidae, 3 of Cyprinidae, 1 of Heleostomatidae, and 4 of Poecilidae) were collected for the purpose of detecting metazoan and protozoan parasites. Parasites were fixed and stained using routine methods, and identified. We found 3 ciliates, 2 monogeneans, 1 nematode, and 1 copepod from 7 host species. Of these, Ichthyophthirius multifiliis was the most common parasite in our study, and together with Trichodina sp., caused mass mortality of Sumatra barb Puntius tetrazona at 1 farm. We also found Camallanus cotti and Tetrahymena corlissi from guppies Poecilia reticulata, both for the first time in Korea. Farmers consider these 2 pathogens to be the most serious ones in Korea. Gussevia asota from oscar Astronotus ocellatus, and Gyrodactylus bullatarudis from platy Xiphophorus maculatus were also found in Korea for the first time. We believe that appropriate quarantine practices for tropical ornamental fishes should be introduced because the failure to require and implement quarantines has already resulted in the accidental introduction of exotic parasites to fish farms, and because these parasites can cause further economic losses if they become established in the wild.
\end{abstract}

KEY WORDS: Parasites · Tropical fishes · Quarantine practice

Resale or republication not permitted without written consent of the publisher

When trading live animals or animal products, quarantine practices should be implemented in order to prevent the introduction of transmissible pathogens which can cause serious outbreaks of disease and consequent economic losses. Aquatic animals are no exception. The Office International des Epizooties (OIE) has detailed provisions for the import and export of aquatic animals and aquaculture products aimed at

*Present address: R\&D division, RNL Life Science Co. Ltd, 5-2 Seodun-dong, Suwon, Kyungki-do, 441-100, Korea. E-mail: aqua@rnllifescience.com avoiding the risk of spreading aquatic animal diseases (OIE 1997). However, ornamental fishes are not included in these provisions and, in fact, in many countries, the tropical ornamental fish trade operates without appropriate quarantine practices. These fish may cause problems in the importing country, since they can die of infections soon after their arrival, or during transportation, resulting in economic losses. Recently, mortalities have occurred in some tropical fish farms in Korea, and a number of parasites were observed in these fishes. Here we aim to investigate parasites of tropical ornamental fishes imported to Korea and to determine if they are associated with these fish farm mortalities.

Materials and methods. We collected freshwater tropical ornamental fishes soon after importation at 8 different tropical fish farms located in Kyungki and Chungbuk Province in the center of the Korean Peninsula, during November and December 2000. The scientific names of the fishes we collected are listed in Table 1. We euthanized the fish in $500 \mathrm{ml}$ water containing several drops of 2-phenoxyethanol (Sigma) and dissected them under the microscope. We examined the body surface of fish carefully to detect metazoan and protozoan parasites, and then dissected them to investigate internal parasites. Mucus was scraped from the skin and gills with a cover glass, and fresh smears were prepared on slides in a drop of water under a coverslip and then examined for protozoan parasites. If trichodinids or Tetrahymena were detected, new smears were prepared and slides were air-dried, impregnated with a $2 \%$ silver nitrate solution for 20 min, and exposed to ultraviolet radiation for $30 \mathrm{~min}$. If other protozoans were detected, new smears were airdried and stained with May-Grunwald solutions (Sigma) for $5 \mathrm{~min}$, washed with PBS briefly, then stained with Giemsa solution (BDH Chemicals, 1:20 
Table 1. A list of host fish species and the total number of each fish sampled in our study

\begin{tabular}{|llr|}
\hline Family/Fish species & Common name & Sample size (n) \\
\hline Characidae & & \\
Gymnocorymbus ternetzi (Boulenger, 1895) & Black tetra & 20 \\
Cichlidae & & 3 \\
Astronotus ocellatus (Agassiz, 1831) & Oscar & 20 \\
Heros severus Heckel, 1840 & Banded cichlid & 2 \\
Julidochromis dickfeldi Staeck, 1975 & Dickfeld's cichlid & 5 \\
Labidochromis caeruleus Fryer, 1956 & Blue streak hap & 1 \\
Nimbochromis venustus (Boulenger, 1908) & Venus cichlid & 20 \\
Pterophyllum scalare (Lichtenstein, 1823) & Freshwater angelfish \\
Cyprinidae & & 11 \\
Balantinocheilos melanopterus (Bleeker, 1851) & Tricolor sharkminnow \\
Epalzeorhynchos frenatum (Fowler, 1934) & Rainbow sharkminnow \\
Puntitus tetrazona (Bleeker, 1855) & Sumatra barb & 2 \\
Heleostomatidae & & 21 \\
Heleostoma temminckii Cuvier, 1829 & Kissing gourami \\
Poecilidae & & 20 \\
Poecila sphenops Valemciemmes, 1846 & Black molly \\
Poecilia reticulata Peters, 1860 & Guppies \\
Xiphophorus helleri Heckel, 1848 & Swordtail \\
Xiphophorus maculates (Gunther, 1860) & Platy & 30 \\
& & 23 \\
\end{tabular}

diluted with distilled water) for $20 \mathrm{~min}$ and washed with distilled water. Coverslips were mounted on stained specimens with a small drop of malinol (Toho Chemical) after air-drying, then the preparations were examined. For monogeneans, we mounted worms in a small drop of distilled water under a coverslip. Worms were then fixed with APG (ammonium picrate glycerine), after flattening the preparations to the required degree. For nematodes, we fixed worms in hot $70 \%$ ethanol, and cleared them in glycerine on microscope slides for examination. For copepods, we fixed adults in $70 \%$ ethanol, and examined them under a dissecting microscope. We examined the fish only for external parasites on the body surface and the gills, and for gut parasites.

Results. We detected a total of 7 parasites on 7 of the 15 host species examined (Table 2): 3 ciliates (Ichthyophthirius multifiliis, Tetrahymena corlissi, Trichodina sp.), 2 monogeneans (Gyrodactylus bullatarudis, Gussevia asota), 1 nematode (Camallanus cotti), and 1 copepod (Lernaea cyprinacea). Two hosts, Sumatra barb Punctius tetrazona and guppy Poecilia reticulata, were infected with 2 species each (I. multifiliis and Trichodina sp. and T. corlissi and C. cotti, respectively).

Table 2. Parasites detected in a total of 351 tropical pet fishes (1 species of Characidae, 6 Cichlidae, 3 Cyprinidae, 1 Heleostomatidae, 4 Poecilidae) imported to Korea. Prevelance of infection (\%)

\begin{tabular}{|c|c|c|c|}
\hline Parasite species & Host species & Site of infection & Prevalence (\%) \\
\hline \multicolumn{4}{|l|}{ Ciliates } \\
\hline \multirow[t]{3}{*}{ Ichthyophthirius multifiliis } & Balantinocheilos melanopterus & Skin & 54.5 \\
\hline & Epalzeorhynchos frenatum & Skin & 100 \\
\hline & Puntitus tetrazona & Skin & 100 \\
\hline Tetrahymena corlissi & Poecilia reticulata & Skin & 7.2 \\
\hline Trichodina sp. & Puntitus tetrazona & Skin & 100 \\
\hline \multicolumn{4}{|l|}{ Monogeneans } \\
\hline Gyrodactylus bulltarudis & Xiphophorus maculates & Fin & 5 \\
\hline Gussevia asota & Astronotus ocellatus & Gills & 66.7 \\
\hline \multicolumn{4}{|l|}{ Nematodes } \\
\hline Camallanus cotti & Poecilia reticulata & Intestine & 14.4 \\
\hline \multicolumn{4}{|l|}{ Copepods } \\
\hline Lernaea cyprinacea & Poecilia sphenops & Skin & 3.3 \\
\hline
\end{tabular}


Ichthyophthirius multifiliis (Fouquet, 1876) was the most common parasite in our study. We found I. multifiliis from 3 host species, and all of the infected individuals were heavily infected. Of these 3 hosts, Sumatra barb were also infected with Trichodina sp. simultaneously. All the individuals we examined were infected with both parasites. Tetrahymena corlissi was found on $7.2 \%$ of guppies we examined, and Camallanus cotti in $14.4 \%$ of them (Table 2 ).

We examined 6 species of Cichlidae, but found only 1 monogenean (Gussevia asota) from 1 host (Astronotus ocellatus) and the prevalence of infection was $66.7 \%$ (Table 2). Another monogenean (Gyrodactylus bullatarudis) was found from 1 Poecilidae (Xiphophorus maculatus), but the prevalence of infection was very low (5\%, Table 2$)$. We also found a copepod, Lernaea cyprinacea, infesting black molly Xiphophorus sphenops.

Discussion. We found a total of 7 species of parasites among 15 species of ornamental fishes in this survey (Table 2). This is the first report on the parasites of tropical ornamental fishes imported to Korea, and of the 7 parasites found, the 2 monogeneans are thought to be exotic to Korea. In the case of other parasites, it is unclear whether they are exotic or native.

Ichthyophthirius multifiliis is a widely distributed ectoparasite, and probably occurs worldwide (Lom \& Dykova 1992). We found an outbreak in 3 host species from 2 farms in this survey, and there was a mass mortality in Sumatra barb at 1 farm. It was difficult to determine the cause of death in this case, however, because we also found Trichodina sp. in the same stock. Trichodinids are essentially commensals and never occur in large numbers on healthy fish. However, in stressed conditions caused by some other factors such as poor water quality, overcrowding, they can proliferate massively and behave like serious ectoparasites (Lom \& Dykova 1992). We suspect that both poor conditions and I. multifiliis infection facilitated the proliferation of Trichodina sp. and caused the death of the host in this outbreak.

Tetrahymena corlissi Thompson, 1955 is a histophagous ciliate and sometimes fatal to its host (Lom \& Dykova 1992). It is known as a causative agent of 'Tet' disease of tropical aquarium fishes and is now causing a serious problem in the ornamental fish culture industry in Southeast Asia (Ponpornpisit et al. 2001). Although it is not clear if this protozoan is an exotic or native species in Korea, it seems to be already established in tropical fish farms in Korea, and is causing serious economic losses. Because Tetrahymena species can infect other poecilids, especially when the water quality is poor and the fish are immunologically depressed (see Lom \& Dykova 1992, Gratzek 1993), it may cause even more serious problems in tropical fish farms in Korea in the future if an appropriate control method is not applied.

The nematode Camallanus cotti Fujita, 1927 was first reported from freshwater fishes in Japan (Fujita 1927) and is reported from many hosts from many countries (see Moravec \& Nagasawa 1989). Its worldwide distribution is thought to be due to the introduction of poecilids, either as aquarium fish or for mosquito control, from Southeast Asia (Font \& Tate 1994, Rigby et al. 1997). However, C. cotti is unlikely to be an exotic species in Korea, because many of the known host species of $C$. cotti reported in China and Japan are also native to Korea (Kim et al. 2002). On the other hand, C. cotti found in domestic guppies, which have been reared in Korea for several years, might have originated from imported fish which were already infected at the time of importation. Other poecilids such as swordtail Xiphophorus helleri are also susceptible to C. cotti infection (Font \& Tate 1994). Thus, this parasite can be a threat to tropical fish farms if it spreads to other poecilids, which are the most common tropical ornamental fishes in Korea.

The monogenean Gussevia asota Kritsky, Thatcher \& Boeger 1989 was described from oscar Astronotus ocellatus, and Kritsky et al. (1989) mentioned that $G$. asota apparently can cause the death of its host, citing the case of an aquarium in Idaho, USA, as an example. In our study, we could not determine how widely this parasite is distributed in Korea because the 3 host specimens we collected came from 1 farm only, and the number of the specimens was small. Farmers could not recall any outbreaks in oscars. Nevertheless, all monogeneans are potential pathogens to their hosts when fish are crowded together, such as in fish farms.

Another monogenean, Gyrodactylus bullatarudis Turnbull, 1956, was first described from guppies, and has also been reported from black molly Poecilia sphenops, and Xiphophorus hybrids $(X$. helleri $\times$ $X$. maculatus) (see Harris 1986). Except for guppies, there are few records for gyrodactylids from poecilid fishes, and only 2 Gyrodactylus species (G. rasini and $G$. bullatarudis) have been reported from the genus Xiphophorus (see Harris \& Cable 2000). Hence, this is the first report on this gyrodactylid parasite in platy $X$. maculatus. Although host specificity has been used for identification of the genus Gyrodactylus, these parasites can infect other fishes if the environmental conditions are not optimal for them (see Cable et al. 1999). Our single specimen was morphologically inseparable from G. bullatarudis. This monogenean is likely to have harmful effects not only on guppies, but also on other poecilids, because it can switch to other hosts in confined environments or in stressful conditions.

The copepod Lernaea cyprinacea Linnaeus, 1758 has a broad host range including ornamental fish, frog tad- 
poles and even salamanders, and can cause serious damage in both the aquaculture industry and natural environment of importing countries where this copepod is exotic (Hoffman 1998). This copepod has a worldwide distribution, partly because of the international trade of tropical fishes (Robinson \& AvenantOldewage 1996). Its pathogenicity is well-known because it can cause serious mortality due to hemorrhages and secondary bacterial infections, especially in cases of heavy infestations (Gratzek 1993).

The tropical aquarium fish trade constitutes a significant portion of worldwide trade in aquatic animals (Evans \& Lester 2001), and a large number of imported ornamental fish originate from Southeast Asian countries. Korea also imports various kinds of tropical aquarium fishes from Southeast Asian countries; the scale and number of imported species are increasing. However, most fishes are imported without quarantine, and consequently, the fishes infected with undetected pathogen(s) can be distributed to retailers and sold to consumers.

These fishes can cause problems to importing countries in 2 respects. Infected fish sometimes die during transportation or soon after arrival, due to the combination of stress and pathogen infection, and this results in immediate economic losses. From an environmental perspective, infected fish can cause problems to indigenous fish species if they escape into the natural environment of the importing countries. There are several good examples of epidemic mortalities in wild fish populations associated with the ornamental fish trade; several protozoans (e.g. Chilodonella cyprini, Ichthyobodo sp., I. multifiliis, Trichodina sp.) and metazoans (e.g. Dactylogyrus sp., Gyrodactylus sp.) are thought to have been introduced into Australia with the importation of ornamental fishes and to have caused consequent mortalities in native fish species (see AQIS 1999). Other examples of mortalities are also known from fishes meant for human consumption. For example, Norway suffered huge losses of wild salmon populations because of the accidental introduction of Gyrodactylus salaris into the natural environment (Jonsen \& Jensen 1991). Similarly, the Japanese aquaculture industry was seriously affected by the accidental introduction of Neobenedenia girellae (synonym, N. melleni), probably with amberjack Seriola dumerli fry in unregulated shipments from China (Ogawa et al. 1995). Hence, it is clear that the accidental introduction of exotic parasites can have harmful effects both directly by reducing profits and by negatively impacting the natural environments of importing countries. We cannot predict what the consequences are likely to be when the exotic pathogens are introduced in the importing countries, due to the limited information on the factors relevant to the establishment of exotic pathogens to the importing countries (see AQIS 1999). Hence, to avoid the introduction of fish pathogens it is necessary to introduce quarantine practices to the ornamental fish trade, as well as to the trade in fish for human consumption. Until such laws have been introduced, ornamental fishes should be examined, either on an ad hoc or routine basis, to confirm that they are pathogen-free; if they are infected, appropriate treatments should be administered before clearance. Importing countries should also examine imported fishes and treat them before domestic distribution.

Acknowledgements. We thank the tropical ornamental fish farmers for giving us fish samples, and Mr. Byong-Gu Jeon and Mr. Young-Soo Lee in the same laboratory for their assistance during the research.

\section{LITERATURE CITED}

AQIS (1999) Import risk analysis on live ornamental fish. Australian Quarantine and Inspection Service, Canberra

Cable J, Harris PD, Tinsly RC, Lazarus CM (1999) Phylogenetic analysis of Gyrodactylus spp. (Platyhelminthes: Monogenea) using ribosomal DNA sequences. Can J Zool 77:1439-1449

Evans BB, Lester RJG (2001) Parasites of ornamental fish imported to Australia. Bull Eur Assoc Fish Pathol 21:51-55

Font, WF, Tate DC (1994) Helminth parasites of native Hawaiian freshwater fishes: an example of extreme ecological isolation. J Parasitol 80:682-688

Fujita T (1927) On new species of nematodes from fishes of Lake Biwa. Jap J Zool 1:169-176

Gratzek JB (1993) Parasites associated with freshwater tropical fishes. In: Stoskopf MK (ed) Fish medicine. WB Saunders Company, Philadelphia, PA, p 573-590

Harris PD (1986) Species of Gyrodactylus von Nordmann, 1832 (Monogenea Gyrodactylidae) from poeciliid fishes, with a description of $G$. turnbulli sp. nov. from the guppy, Poecilia reticulata Peters. J Nat His 20:183-191

Harris PD, Cable J (2000) Gyrodactylus poeciliae n. sp. and G. milleri n. sp. (Monogenea: Gyrodactylidae) from Poecilia caucana (Steindachner) in Venezuela. Syst Parasitol 47: $79-85$

Hoffman GL (1998) Parasites of North American freshwater fishes, 2nd edn. Cornell University Press, Ithaca, NY, p $317-319$

Jonsen BO, Jensen AJ (1991) The Gyrodactylus story in Norway. Aquaculture 98:289-302

Kim JH, Hayward CJ, Heo, GJ (2002) Nematode worm infections (Camallanus cotti; Camallanidae) in guppies (Poecilia reticulata) imported to Korea. Aquaculture 205:231-235

Kritsky DC, Thatcher VE, Boeger WA (1989) Neotropic monogenea. 15. Dactylogyrids from the gills of Brazilian Cichlidae with proposal of Sciadicleithrum gen. n. (Dactylogyridae). Proc Helmonthol Soc Wash 56:128-140

Lom J, Dykova I (1992) Protozoan parasites of fishes. Developments in Aquaculture and Fisheries Science 26. Elsevier, Amsterdam, p 253

Moravec F, Nagasawa K (1989) Observations on some nematodes parasitic in Japanese freshwater fishes. Folia Parasitol 36:127-141 
Ogawa K, Bondad-Reantaso M, Fukudome M, Wakabayashi H (1995) Neobenedenia girellae (Hargis, 1955) Yamaguti, 1963 (Monogenea: Capsalidae) from cultured marine fish of Japan. J Parasitol 81:223-227

OIE (1997) International aquatic animal health code. Office International des Epizooties, Paris, p 267

Ponpornpisit A, Endo M, Murata H (2001) Prophylactic effects of chemicals and immunostimulants in experimental

Editorial responsibility: Wolfgang Körting,

Hannover, Germany
Tetrahymena infections of guppy. Fish Pathol 36:1-6

Rigby MC, Font WF, Deardorff TL (1997) Redescription of Camallanus cotti Fujita, 1927 (Nematoda, Camallanidae) from Hawai'i. J Parasitol 83:1161-1164

Robinson J, Avenant-Oldewage A (1996) Aspects of the morphology of the parasitic copepod Lernaea cyprinacea Linnaeus, 1758 and notes on its distribution in Africa. Crustaceana 69:610-626

Submitted: July 30, 2001; Accepted: May 29, 2002

Proofs received from author(s): October 7, 2002 